\title{
Hemoptysis and Pulmonary Edema in a Scuba Diver Using Diclofenac
}

\author{
Dirk Van Renterghem Charlotte Depuydt \\ Clinical Department of Pulmonology, AZ Sint Jan Brugge-Oostende, Brugge, Belgium
}

\section{Key Words}

Diclofenac · Hemoptysis - Pulmonary edema • Scuba diver

\begin{abstract}
Hemoptysis and pulmonary edema associated with nonsteroidal anti-inflammatory drug use is a known condition, but is probably underreported. The mechanisms of induction of pulmonary toxicity are still not well understood. We describe a case of hemoptysis and dyspnea in a scuba diver who was taking diclofenac.

Copyright $\odot 2012$ S. Karger AG, Basel
\end{abstract}

\section{Introduction}

We read with interest the short communication of Dr. Yiannakopoulou 'Hemoptysis under diclofenac and antiplatelet doses of aspirin' [1], which came to our attention after seeing a patient who developed dyspnea and rosecolored frothy sputum while scuba diving - he had been taking diclofenac in high doses for several weeks.

\section{Case Report}

A 56-year-old man, ex-smoker but in good condition, was taking losartan $50 \mathrm{mg} /$ day for mild arterial hypertension, pravastatin $20 \mathrm{mg} /$ day for dyslipidemia and used CPAP $7 \mathrm{~cm}$ overnight for obstructive sleep apnea. In May 2011 he started diclofenac $2 \times$ $100 \mathrm{mg} /$ day for a painful right foot. Since he was an experienced scuba diver, he went scuba diving in the Red Sea in June 2011. The water temperature was $28^{\circ} \mathrm{C}$. He used a gas mixture of $30 \% \mathrm{O}_{2}$, and his clothing was not tight. A first dive was accompanied by strenuous swimming against a current. At a depth of $25 \mathrm{~m}$ after $25 \mathrm{~min}$, he experienced dyspnea and some cough, therefore he decided to ascend. The day after he went diving again, without much exercise. After $10 \mathrm{~min}$ and again at $25 \mathrm{~m}$, he experienced severe shortness of breath and irresistible cough. After ascent he coughed rose-colored frothy sputum, but the dyspnea and cough quickly disappeared. One month later, after returning home, he presented for examination. Clinical and all supplementary examinations proved normal: chest X-ray, CT of the thorax, laboratory (including clotting tests, D-dimers, autoimmune antibodies), lower extremity venous duplex sonography (except for some varicose veins), ventilation-perfusion lung scan, bronchoscopy, and echocardiography.

\section{Discussion}

Although imaging in the acute stage is lacking, the history suggests the combination of pulmonary edema and hemoptysis. These are well-known complications of endurance swimming, scuba diving and breath-hold diving, demonstrated by many publications [2-6]. Arterial hypertension, smoking and aspirin ingestion are sometimes considered contributing elements. Common to all is microvascular stress due to high pulmonary capillary pressure and pulmonary overperfusion (due to cold water

\section{KARGER}

Fax +4161306 1234

E-Mail karger@karger.ch

www.karger.com
(C) 2012 S. Karger AG, Basel

0031-7012/12/0892-0103\$38.00/0

Accessible online at:

www.karger.com/pha
Charlotte Depuydt

Clinical Department of Pulmonology

Ruddershove 10

BE-8000 Brugge (Belgium)

Tel. +32 5045 2660, E-Mail charlotte_depuydt@yahoo.com 
immersion, loss of orthostasis, tight suits and increased cardiac output by exercise) and increased transalveolar pressure due to increased respiratory effort.

On the other hand numerous publications illustrate that aspirin and likely nonsteroidal anti-inflammatory drugs (NSAIDs) can damage capillary integrity leading to pulmonary edema or hemoptysis [7-10].

The website www.pneumotox.com, an initiative of the Groupe d'Etudes de la Pathologie Pulmonaire Iatrogène [7], under the impulse of Dr. Philippe Camus in France, holds practical, comprehensive and up-to-date information on pulmonary damage due to drugs, and also mentions other pulmonary side effects of aspirin and NSAIDs such as asthma, pneumonitis, bronchiolitis obliterans with organizing pneumonia, diffuse alveolar damage, eosinophilic infiltrates, vasculitis or pleural fluid [7].
Further, Yiannakopoulou [1] amply discussed the effects of aspirin and diclofenac and other NSAIDs on platelet function, related to cyclo-oxygenase 1 inhibition and possibly to reactive oxygen species modulation and thromboxane receptor antagonism. Tuleja et al. [11] showed that the intensity of these differential effects is not the same for all NSAIDs.

\section{Conclusion}

Apparently, diclofenac should be added to the list of NSAIDs responsible for pulmonary edema and hemoptysis. It is likely that these side effects are underreported. Moreover, high doses of aspirin and NSAIDs could be discouraged in situations that stress pulmonary capillaries such as high-intensity water sports.

\section{References}

-1 Yiannakopoulou E: Hemoptysis under diclofenac and antiplatelet doses of aspirin. Pharmacology 2011;87:1-4.

$>2$ Boussuges A, Pinet C, Thomas P, Bergmann E, Sainty J, Vervloet D: Hemoptysis after breath hold diving. Eur Respir J 1999;13: 697-699.

$>3$ Koehle MS, Lepawsky M, McKenzie DC: Pulmonary oedema of immersion. Sports Med 2005;35:183-190.

$>4$ Henckes A, Lion F, Cochard G, Arvieux J, Arvieux C: L'oedème pulmonaire en plongée sous-marine autonome: fréquence et gravité à propos d'une série de 19 cas (Pulmonary oedema in scuba-diving: frequency and seriousness about a series of 19 cases). Ann Fr Anesth Reanim 2008;27:694-699.
5 Linér MH, Andersson JP: Pulmonary edema after competitive breath-hold diving. J Appl Physiol 2008;104:986-990.

6 Knutson T: Swimming-induced pulmonary oedema, a hazard in intensive military training? J R Army Med Corps 2010;156:258-259.

7 www.pneumotox.com The website of the Groupe d'Etudes de la Pathologie Pulmonaire Iatrogène.

$>8$ Glisson J, Vesa T, Bowling M: Current management of salicylate-induced pulmonary edema. South Med J 2011;104:225-232.
9 Bowers R, Brigham K, Owen P: Salicylate pulmonary edema: the mechanism in sheep and review of the clinical literature. Am Rev Respir Dis 1977;115:261-268.

10 Schwarz M: Pulmonary vasculitis and hemorrhage; in Albert R, Spiro S, Jett J (eds): Clinical Respiratory Medicine, ed 3. London, Mosby, 2008, pp 797-807.

-11 Tuleja E, Mejza F, Cmiel A, Szczeklik A: Effects of cyclooxygenase inhibitors on vasoactive prostanoids and thrombin generation at the site of microvascular injury in healthy men. Arterioscler Thromb Vasc Biol 2003. 23:1111-1115. 